\title{
Genetic engineering of Clostridium thermocellum DSM1313 for enhanced ethanol production
}

\author{
Saranyah Kannuchamy, Nisha Mukund and Lilly M. Saleena*
}

From Indian Genetics Congress 2015

Kattankulathur, India. 4-6 March 2015

\begin{abstract}
Background: The twin problem of shortage in fossil fuel and increase in environmental pollution can be partly addressed by blending of ethanol with transport fuel. Increasing the ethanol production for this purpose without affecting the food security of the countries would require the use of cellulosic plant materials as substrate. Clostridium thermocellum is an anaerobic thermophilic bacterium with cellulolytic property and the ability to produce ethanol. But its application as biocatalyst for ethanol production is limited because pyruvate ferredoxin oxidoreductase, which diverts pyruvate to ethanol production pathway, has low affinity to the substrate. Therefore, the present study was undertaken to genetically modify C. thermocellum for enhancing its ethanol production capacity by transferring pyruvate carboxylase ( $p d c)$ and alcohol dehydrogenase ( $a d h$ ) genes of the homoethanol pathway from Zymomonas mobilis.

Results: The pdc and adh genes from Z. mobilis were cloned in pNW33N, and transformed to Clostridium thermocellum DSM 1313 by electroporation to generate recombinant CTH-pdc, CTH-adh and CTH-pdc-adh strains that carried heterologous $p d c$, adh, and both genes, respectively. The plasmids were stably maintained in the recombinant strains. Though both $p d c$ and adh were functional in C. thermocellum, the presence of adh severely limited the growth of the recombinant strains, irrespective of the presence or absence of the pdc gene. The recombinant $\mathrm{CTH}$-pdc strain showed two-fold increase in pyruvate carboxylase activity and ethanol production when compared with the wild type strain.

Conclusions: Pyruvate decarboxylase gene of the homoethanol pathway from Z mobilis was functional in recombinant $C$. thermocellum strain and enhanced its ability to produced ethanol. Strain improvement and bioprocess optimizations may further increase the ethanol production from this recombinant strain.
\end{abstract}

Keywords: Clostridium thermocellum, homoethanol pathway, Zymomonas mobilis, pdc, adh

\footnotetext{
* Correspondence: Saleena.m@ktr.srmuniv.ac.in

Department of Bioinformatics, School of Bioengineering, SRM University,

Kattankulathur 603203, Tamil Nadu, India
}

(c) 2016 Kannuchamy et al. Open Access This article is distributed under the terms of the Creative Commons Attribution 4.0 International License (http://creativecommons.org/licenses/by/4.0/), which permits unrestricted use, distribution, and reproduction in any medium, provided you give appropriate credit to the original author(s) and the source, provide a link to the Creative Commons license, and indicate if changes were made. The Creative Commons Public Domain Dedication waiver (http://creativecommons.org/publicdomain/zero/1.0/) applies to the data made available in this article, unless otherwise stated. 


\section{Background}

Blending of ethanol with fossil fuel is recommended to address the problem of increasing demand for transportation fuel without environmental pollution. This implementation was planned because ethanol is derived from renewable biological sources, and has promising properties such as anti-knock potential $[1,2]$ and cleaner combustion [3, 4]. Several countries around the world are adopting this strategy, and are planning to increase the percentage of ethanol blending in a phased manner [5]. In this context, allocation of natural resources for ethanol production in place of food production, and completing interests in ethanol for industrial and potable purposes are the major concerns to be addressed. For example, sugarcane molasses serves as the sole feedstock for bioethanol production in India where the annual production is approximately 2.7 billion litres of which only $30 \%$ is offered for fuel purposes $[6,7]$. When considering the supply of feedstock, increasing the production of ethanol from sugarcane molasses is questionable because land allocation for sugarcane cultivation is limited [8], and it requires 20 megalitres of water per hectare [9]. Diverting land and water resources from production of food crops such as wheat and rice to sugarcane will threaten the food security of the countries. Therefore, plant materials from forests, urban wastes, and agricultural wastes were considered for their utility as feedstock for ethanol production [10].

A revolution of using cellulosic agricultural wastes such as corn stalk, wheat and rice straw, husk, and bran as feedstock for ethanol production was explored in many countries. Microorganisms having the capacity of utilizing cellulosic substrates for ethanol production were exploited for this purpose [11]. Clostridium thermocellum is one of the most efficient cellulolytic microorganisms due to the presence of cellulosomes that bind and metabolize cellulose and hemicellulose [12]. It is an anaerobic, thermophilic, and ethanol producing organism, which can be used as a biocatalyst for ethanol production from cellulosic substrates. However, the ethanol production pathway of $C$. thermocellum is not efficient because pyruvate ferrodoxin oxidoreductase, the key enzyme of this pathway [13], has lower affinity than lactate dehydrogenase and phosphotransacetylase towards the common substrate, pyruvate. As a result, the yield of ethanol is reduced, and other undesirable by-products like acetic acid and lactic acid accumulate [14-16].

Zymomonas mobilis has a distinctive Entner-Doudoroff pathway to metabolize glucose to pyruvate [14], and also a homoethanol pathway to metabolize pyruvate to ethanol. Two key enzymes of homoethanol pathway are pyruvate decarboxylase and alcohol dehydrogenase, which convert pyruvate to acetaldehyde and acetaldehyde to ethanol, respectively. Genes coding for these two enzymes from $Z$. mobilis were successfully used for metabolic engineering of enhanced ethanol production in Geobacillus thermoglucosidasus [15], Escherichia coli [16], Clostridium cellulolyticum [17], and Synechococcus sp. [18]. The present study reports genetic modification of $C$. thermocellum for enhanced ethanol production by introducing the pyruvate decarboxylase and alcohol dehydrogenase genes from $Z$. mobilis. The recombinant $C$. thermocellum strains were analysed for the expression of the cloned genes and ethanol production efficiency.

\section{Results and discussion}

The present study explored the possibility of enhancing the ethanol production capacity of Clostridium thermocellum by transferring pyruvate decarboxylase $(p d c)$ and alcohol dehydrogenase $(a d h)$ genes from Zymomonas mobilis. The $p d c$ and $a d h$ genes were successfully PCR amplified and cloned in pNW33N to obtain pNW33N$p d c, \mathrm{pNW} 33 \mathrm{~N}-a d h$, and pNW33N-pdc-adh, which contained $p d c, a d h$ and both genes, respectively. The vector contained chloramphenicol acetyltransferase gene, which functions in gram negative and gram positive bacteria [19]. C. thermocellum is a difficult species for plasmid transformation due to endospore formation and strict anaerobic growth [20]. Electroporation method of plasmid transformation in C. thermocellum was illustrated by Olson and Lynd [21], and increasing the pulse duration and amplitude improved the transformation efficiency of larger plasmids [22]. In the present study, pNW33N-adh $(5.3 \mathrm{~Kb})$ was the smallest plasmid, followed by pNW33N-pdc $(5.9 \mathrm{~Kb})$ and pNW33N-pdc$a d h(7.0 \mathrm{~Kb})$. We have varied the pulse duration from 1.0 to 3.0 milliseconds (ms), and amplitude from 1500 to $2000 \mathrm{~V}$ in order to get successful transformation. A transformation efficiency of $1.5 \times 10^{3} / \mu \mathrm{g}, 1.0 \times 10^{3} / \mu \mathrm{g}$, and $0.85 \times 10^{3} / \mu \mathrm{g}$ was obtained for pNW33N-adh, pNW33N-pdc, and pNW33N-pdc-adh by applying $1.5 \mathrm{~ms}$ with $1500 \mathrm{~V}, 2.0 \mathrm{~ms}$ with $1600 \mathrm{~V}$, and $3.0 \mathrm{~ms}$ with $1800 \mathrm{~V}$, respectively. Bigger plasmids required longer pulse duration and higher amplitude of voltage for successful transformation. The recombinant stains were continuously sub-cultured ten times in CTFUD medium supplemented with $6.0 \mathrm{mg} / \mathrm{L}$ thiamphenicol, and genetic stability was monitored after every sub-culture $(72 \mathrm{~h}$ each). The plasmids were found to be stably retained in the recombinant strains as determined by colony PCR amplification of plasmid-borne genes.

Growth profile of the wild type and recombinant strains was monitored every $24 \mathrm{~h}$ for $96 \mathrm{~h}$ after inoculation. Growth of $C$. thermocellum can be visually observed by the development of a deep yellow tinge in the growth medium due to the release of an insoluble yellow affinity substance as a result of cellulose utilization by the organism $[23,24]$. Wild type and the recombinant 
$\mathrm{CTH}-p d c$ strain developed the deep yellow tinge $24 \mathrm{~h}$ after inoculation indicating cellulose utilization and growth. In contrast, the recombinant $\mathrm{CTH}-a d h$ and $\mathrm{CTH}-p d c-a d h$ strains developed the deep yellow tinge only after $48 \mathrm{~h}$. Considering the turbidity caused by the cellulose in the medium as hindrance, growth of $C$. thermocellum in CTFUD medium was monitored by estimating protein content instead of measuring the optical density. The comparative growth pattern of the wild type and recombinant strains is illustrated in Fig. 1. Growth rate of recombinant $\mathrm{CTH}-p d c$ strain was comparable with that of the wild type strain. However, the growth rate of the recombinant strain that carried either $a d h$ gene alone or $a d h$ and $p d c$ genes showed significantly lower growth rate when compared with wild type or recombinant CTH-pdc strain. The same was observed when these constructs were present in $E$. coli, which may be due to the reverse catalysis of ethanol to acetaldehyde by alcohol dehydrogenase [25].

Metabolically engineered Klebsiella oxytoca with the pyruvate decarboxylase gene from $Z$. mobilis was reported to augment its pyruvate decarboxylation capacity [26]. C. thermocellum contains native pyruvate ferredoxin oxidoreductase enzyme for the decarboxylation of pyruvate to which the recombinant pyruvate decarboxylase enzyme from $Z$. mobilis was added by genetic engineering. Cell free extracts from the fermented cultures of wild type and recombinant $\mathrm{CTH}-p d c$ strains were assayed for pyruvate decarboxylation based on pyruvatedependant reduction of $\mathrm{NAD}^{+}$. The recombinant $\mathrm{CTH}-$ $p d c$ strain showed faster reduction of $\mathrm{NAD}^{+}$than the wild type strain (Fig. 2). Specific activity of PDC was 0.6 $\mathrm{U} / \mathrm{mg}$ in the wild type and $1.8 \mathrm{U} / \mathrm{mg}$ in the recombinant $\mathrm{CTH}-p d c$. These results showed that the pyruvate decarboxylase from $Z$. mobilis was functional in the recombinant $\mathrm{CTH}-p d c$ strain and enhanced its capacity for pyruvate decarboxylation.

Time course experiment on ethanol production by dichromate oxidation assay, and estimation of ethanol content by gas chromatography were carried out only for the recombinant $\mathrm{CTH}-p d c$ strain. Ethanol concentration remained undetectable in both wild type and $\mathrm{CTH}$ $p d c$ recombinant strain until $24 \mathrm{~h}$. Time dependent increase in ethanol production was observed in $48 \mathrm{~h}$ and $72 \mathrm{~h}$. There was no significant increase in ethanol production beyond $72 \mathrm{~h}$ of fermentation. Therefore, wild type and recombinant $\mathrm{CTH}-p d c$ strains were batch fermented for $72 \mathrm{~h}$, and ethanol was solvent extracted, and analysed in gas chromatography. The CHE-pdc recombinant strain yielded $3.0 \mathrm{~g} / \mathrm{L}$ ethanol $(53 \%$ theoretical ethanol yield) compared to $1.5 \mathrm{~g} / \mathrm{L}$ ethanol ( $26 \%$ theoretical ethanol yield) from the wild type strain. Earlier studies in C. thermocellum have shown theoretical ethanol yield of $51 \%$ by deleting the genes for acetate dehydrogenase and phosphotransacetylase [27], and $69 \%$ by deleting all the genes for hydrogenase activity, except ech gene [28]. Metabolic engineering of Geobacillus thermoglucosidasius with the $p d c$ gene of $Z$. mobilis was also reported to increase the ethanol yield [15]. Two-fold increase in ethanol production reported in the current study due to the recombinant expression of $Z$. mobilis pyruvate decarboxylase gene in $C$. thermocellum indicates the potential of this approach towards developing C. thermocellum as an efficient biocatalyst for ethanol production from cellulosic plant materials. Feedback inhibition of ethanol production and accumulation of growth limiting compounds might be limiting ethanol production beyond $72 \mathrm{~h}$ as indicated by the declining growth rate and static ethanol production. Though there is still scope for further strain improvement by genetic

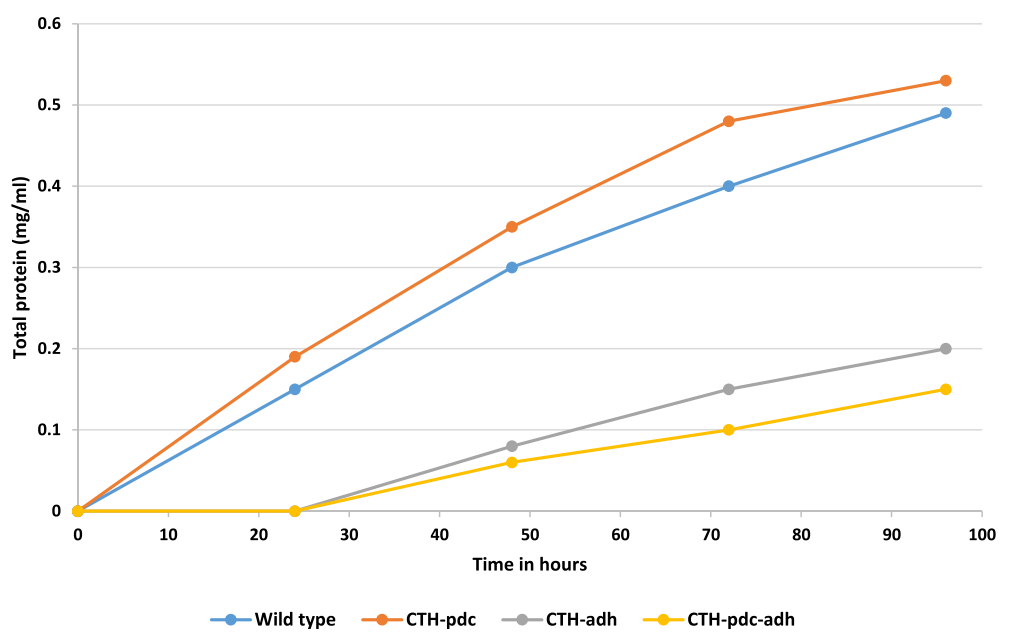

Fig. 1 Growth pattern of wild type and recombinant $\mathrm{CTH}-p d c, \mathrm{CTH}$-adh and $\mathrm{CTH}$-pdc-adh strains measured in terms of increase in protein content with time 


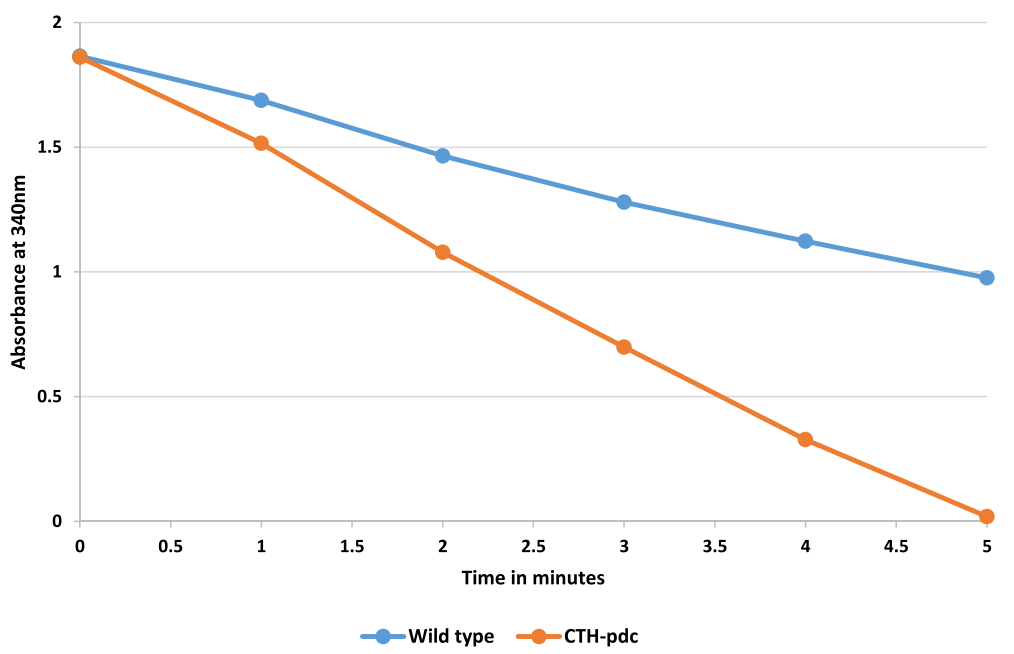

Fig. 2 Pyruvate dependent reduction of $\mathrm{NAD}^{+}$assay in wild type and recombinant $\mathrm{CTH}$-pdc strains

engineering, bioprocess interventions such as simultaneous distillation of ethanol from the fermenting media, fed-batch method of fermentation, and optimization of media and growth conditions may further improve the productivity.

\section{Conclusions}

Cellulolytic potential of C. thermocellum will be highly useful in the green chemistry approach towards the production of ethanol from cellulosic plant materials; however, its ability to produce ethanol from pyruvate is limited. The present study showed that ethanol production from $C$. thermocellum can be enhanced by transferring $p d c$ gene that codes for pyruvate decarboxylase, a key enzyme in the homoethanol pathway of $Z$. mobilis. Further improvement in ethanol production can be warranted by the strain improvement and bioprocess optimization.

\section{Methods}

\section{Bacterial strains}

Clostridium thermocellum DSM1313 was obtained from DSMZ, Germany (https://www.dsmz.de). The organism was cultured and maintained with CTFUD broth and agar media, which comprised of the following components in $\mathrm{g} / \mathrm{L}$; sodium citrate 3.0 , ammonium sulphate 1.3 , calcium chloride 0.13 , L-cysteine $0.5, \beta$-glycerolphosphate 6.0 , ferrous sulphate 0.001 , cellobiose 10.0 , yeast extract 4.5, magnesium chloride 2.6 and potassium dihydrogen phosphate 1.5. The $\mathrm{pH}$ of the medium was maintained at 7.0. Stoppered vials and bottles were used for culturing and maintaining the organism. Cellulose or cellobiose was used as the carbon source. Nitrogen gas was used to maintain anaerobic condition. The incubation temperature was maintained at $60{ }^{\circ} \mathrm{C}$ in a static condition. Zymomonas mobilis was obtained from ATCC, USA (http://www.atcc.org). The organism was inoculated in RM medium ( $\mathrm{pH}$ 6.0), which comprised the following components in $\mathrm{g} / \mathrm{L}$; yeast extract 10.0 , potassium dihydrogen phosphate 2.0 and glucose 20.0. It was grown in the culture flasks kept in orbital shaker at room temperature and $250 \mathrm{rpm}$.

\section{Vector construction}

DNA isolation, PCR amplification and cloning were done by following standard molecular cloning protocols [29]. Gene-specific primers for pyruvate decarboxylase (GenBank Acc. No. HM235920) with 5' BamHI site and 3'XmaI site, and alcohol dehydrogenase (GenBank Acc. No. M15394) with 5' KpnI and 3' EcoRI site were synthesised, and the respective genes were amplified by PCR using the genomic DNA of Z. mobilis as template. The PCR amplified genes were restriction digested and cloned in pNW33N [19], which contained cellobiose phosphorylase promoter [30] and ribosome binding site to facilitate translation [31]. Three separate constructs, each with pyruvate decarboxylase gene (pNW33N-pdc) or alcohol dehydrogenase gene (pNW33N-adh) or both genes (pNW33N-pdc-adh) were transformed to E. coli BL21, and maintained under chloramphenicol selection (34.0 mg/L).

\section{Transformation of $C$. thermocellum}

The plasmid DNA of pNW33N-pdc, pNW33N-adh and pNW33N-pdc-adh were isolated from E. coli BL21, and transformed to $C$. thermocellum by electrotransformation using GenePulser Xcell Electroporator (Bio-Rad, USA). Cells of $C$. thermocellum were grown to an optical density of 0.8 at $600 \mathrm{~nm}$, and $1.0 \mathrm{ml}$ of the culture was transferred to centrifuge tube, and chilled on ice for 
$10 \mathrm{~min}$. The culture was centrifuged at $6500 \mathrm{rpm}$ for $5 \mathrm{~min}$, and the pellet was washed twice with a wash buffer containing $250 \mathrm{mM}$ sucrose and $10 \%$ glycerol, and resuspended in $300 \mu \mathrm{l}$ of the wash buffer. All the above mentioned steps were carried out in an anaerobic cabinet. The cell suspension $(30 \mu \mathrm{l})$ and plasmid DNA (100 ng) were taken in an electroporation cuvette, and desired square pulse and amplitude were applied. The electroporated cells were immediately retrieved, and transferred to CTFUD medium supplemented with 1X concentration of vitamin solution (1000X; pyridoxamine hydrochloride $2000 \mathrm{mg} / \mathrm{L}$, biotin $200 \mathrm{mg} / \mathrm{L}$, and aminobenzoic acid $400 \mathrm{mg} / \mathrm{L}$, and vitamin B12 $200 \mathrm{mg} / \mathrm{L}$ ). The cells were incubated at $51{ }^{\circ} \mathrm{C}$ for $16 \mathrm{~h}$, and plated in CTFUD agar medium supplemented with $6.0 \mathrm{mg} / \mathrm{L}$ thiamphenicol. The transformed colonies were screened by colony PCR using gene speciifc primers, and confirmed by plasmid isolation and restriction digestion. Recombinant $C$. thermocellum containing pNW33N-pdc, pNW33N-adh and pNW33N-pdc-adh plasmids were named as CTH-pdc, CTH-adh and CTH-pdc-adh, respectively. Recombinant $C$. thermocellum strains were always maintained in the presence of thiamphenicol $(6.0 \mathrm{mg} / \mathrm{L})$.

\section{Enzyme assay}

The wild and recombinant $\mathrm{CTH}-p d c$ were grown to an optical density of 0.8 at $600 \mathrm{~nm}$, and $10 \mathrm{ml}$ of the culture was transferred to centrifuge tubes. The culture was centrifuged at 6,000 rpm for $10 \mathrm{~min}$, and the pellet was resuspended in $0.5 \mathrm{ml}$ assay buffer $(0.1 \mathrm{M}$ Tris $-\mathrm{HCl}$, $0.1 \mathrm{mM} \mathrm{FeSO} 4$ and $0.1 \mathrm{mM}$ DTT, pH 7.5). The cells were lysed using $20 \mu \mathrm{l}$ of lysozyme $(10 \mathrm{mg} / \mathrm{ml})$, and the resulting lysate was clarified by treating it with 5.0 units of DNase I. The lysate was centrifuged at $12,000 \mathrm{rpm}$ for $10 \mathrm{~min}$ at room temperature, and the cell free extract (supernatant) was used for enzyme assays. Pyruvate decarboxylase was assayed by measuring pyruvatedependant reduction of $\mathrm{NAD}^{+}$in the presence of alcohol dehydrogenase as the coupling enzyme [32]. Protein concentration was estimated by Bradford method [33]. One unit of enzyme represents the amount of enzyme required for conversion of $1.0 \mu \mathrm{mol}$ of substrate per minute into specific products. Specific activity of the enzyme was calculated by using the extinction coefficient of $\operatorname{NAD}^{+}\left(6.22 \mathrm{~cm}^{-1} \mathrm{mM}^{-1}\right)$ [34].

\section{Fermentation and analysis of ethanol production}

Fresh inoculum was prepared by adding $1 \%$ of stock inoculum to $500 \mathrm{ml}$ of CTFUD medium, and fermenting the culture at $52{ }^{\circ} \mathrm{C}$ for $96 \mathrm{~h}$ without stirring under Nitrogen sparging. The wild type and recombinant $\mathrm{CTH}-p d c, \mathrm{CTH}-a d h$ and CTH-pdc-adh strains were inoculated in the ratio of 1:10 with fresh CTFUD medium in replicates. Batch fermentation was done in 48 stoppered vials, and analysed for ethanol production by dichromate oxidation method [35] at 24, 48, 72 and $96 \mathrm{~h}$ after inoculation. The cultures were immediately transferred to $4{ }^{\circ} \mathrm{C}$ and maintained at the same temperature to avoid the loss of ethanol during storage. Ethanol present in the fermented culture was extracted in tri-nbutyl phosphate and estimated by potassium dichromate oxidation method [36]. Ethanol concentration in the solvent was also measured by gas chromatographic analysis by using flame ionization detector with column at $200{ }^{\circ} \mathrm{C}$. Nitrogen was used as the carrier gas $(30 \mathrm{ml} /$ min), and $n$-butanol was used as internal standard for the quantitative analysis.

\section{Competing interests}

The authors declare that they have no competing interests.

\section{Authors' contributions}

SK participated in the experimental design, performed all the experiments, and drafted the manuscript. NM assisted in the experiments. LMS designed the experiment, evaluated the data, and revised the manuscript. All the authors read and approved the final manuscript.

\section{Acknowledgments}

We acknowledge the financial assistance from Department of Science and Technology (DST), Government of India. We also acknowledge Dr. K. T.

Shanmugam, University of Florida for providing pNW33N plasmid vector.

\section{Declarations}

Publication costs for this article were funded by the corresponding author's institution

This article has been published as part of BMC Biotechnology Volume 16 Supplement 1, 2016: Proceedings of the Indian Genetics Congress 2015: Biotechnology. The full contents of the supplement are available online at http://bmcbiotechnol.biomedcentral.com/articles/supplements/volume-16supplement-1.

Published: 11 May 2016

References

1. Al-Hasan M. Effect of ethanol-unleaded gasoline blends on engine performance and exhaust emission. Energ Convers Manage. 2003;44(9): 1547-61.

2. Boruff P, Schwab A, Goering C, Pryde E. Evaluation of diesel fuel-ethanol microemulsions. T ASAE. 1982;25(1):47-53.

3. Demirbas A. Progress and recent trends in biofuels. Prog Energy Combust Sci. 2007;33(1):1-18

4. Neves AM. Benzene and hydrocarbons. In.: Google Patents, 1982.

5. Government of India. Report of the Committee on Development of Bio-Fuel. New Delhi: Planning Commission, Government of India; 2003.

6. Sukumaran RK. Lignocellulosic ethanol in India: prospects, challenges and feedstock availability. Bioresour Technol. 2010;101(13):4826-33.

7. Zhou A, Elspeth T. The development of biofuels in Asia. Appl Energy. 2009; 86(1):S11-S20

8. Government of India. Agricultural Statistics at a Glance. New Delhi: Department of Economics and Statistics of the Ministry of Agriculture, Government of India; 2008

9. Shrivastava AK, Srivastava AK, Solomon S. Sustaining sugarcane productivity under depleting water resources. Curr Sci (Bangalore). 2011;101(6):748-54.

10. Balat $\mathrm{M}$, Balat $\mathrm{H}$. Recent trends in global production and utilization of bio-ethanol fuel. Appl Energy. 2009;86(11):2273-82.

11. Brethauer $\mathrm{S}$, Wyman CE. Continuous hydrolysis and fermentation for cellulosic ethanol production. Bioresour Technol. 2010;101(13):4862-74.

12. $\mathrm{Ng} \mathrm{T,} \mathrm{Weimer} P$, Zeikus J. Cellulolytic and physiological properties of Clostridium thermocellum. Arch Microbiol. 1977;114(1):1-7. 
13. Lamed R, Zeikus J. Ethanol production by thermophilic bacteria: relationship between fermentation product yields of and catabolic enzyme activities in Clostridium thermocellum and Thermoanaerobium brockii. J Bacteriol. 1980; 144(2):569-78.

14. Rogers PL, Lee KJ, Skotnicki ML, Tribe DE. Ethanol production by Zymomonas mobilis. Microbial Reactions. 1982;23:37-84.

15. Thompson A, Studholme D, Green E, Leak D. Heterologous expression of pyruvate decarboxylase in Geobacillus thermoglucosidasius. Biotechnol Lett. 2008;30(8):1359-65.

16. Ohta K, Beall DS, Mejia JP, Shanmugam KT, Ingram LO. Genetic improvement of Escherichia coli for ethanol production: chromosomal integration of Zymomonas mobilis genes encoding pyruvate decarboxylase and alcohol dehydrogenase II. Appl Environ Microbiol. 1991;57(4):893-900

17. Guedon E, Desvaux M, Petitdemange H. Improvement of cellulolytic properties of Clostridium cellulolyticum by metabolic engineering. Appl Environ Microbiol. 2002;68(1):53-8.

18. Deng MD, Coleman JR. Ethanol synthesis by genetic engineering in cyanobacteria. Appl Environ Microbiol. 1999;65(2):523-8.

19. De Rossi E, Brigidi P, Welker N, Riccardi G, Matteuzzi D. New shuttle vector for cloning in Bacillus stearothermophilus. Res Microbiol. 1994;145(8):579-83.

20. Tyurin MV, Desai SG, Lynd LR. Electrotransformation of Clostridium thermocellum. Appl Environ Microbiol. 2004;70(2):883-90.

21. Olson DG, Lynd LR. Transformation of Clostridium thermocellum by electroporation. Methods Enzymol. 2012;510:317-30.

22. Rhee MS, Kim JW, Qian Y, Ingram LO, Shanmugam KT. Development of plasmid vector and electroporation condition for gene transfer in sporogenic lactic acid bacterium. Bacillus coagulans Plasmid. 2007; 58(1):13-22

23. Freier $\mathrm{D}$, Mothershed $\mathrm{CP}$, Wiegel J. Characterization of Clostridium thermocellum JW20. Appl Environ Microbiol. 1988;54(1):204-11.

24. Ljungdahl L, Pettersson B, Eriksson KE, Wiegel J. A yellow affinity substance involved in the cellulolytic system of Clostridium thermocellum. Curr Microbiol. 1983;9(4):195-9.

25. Kinoshita S, Kakizono T, Kadota K, Das K, Taguchi H. Purification of two alcohol dehydrogenases from Zymomonas mobilis and their properties. Appl Microbiol Biotechnol. 1985;22(4):249-54.

26. Ohta K, Beall D, Mejia J, Shanmugam K, Ingram L. Metabolic engineering of Klebsiella oxytoca M5A1 for ethanol production from xylose and glucose. Appl Environ Microbiol. 1991;57(10):2810-5.

27. Argyros DA, Tripathi SA, Barrett TF, Rogers SR, Feinberg LF, Olson DG, et al. High ethanol titers from cellulose by using metabolically engineered thermophilic, anaerobic microbes. Appl Environ Microbiol. 2011;77(23):8288-94.

28. Biswas R, Zheng T, Olson DG, Lynd LR, Guss AM. Elimination of hydrogenase active site assembly blocks $\mathrm{H} 2$ production and increases ethanol yield in Clostridium thermocellum. Biotechnol Biofuels. 2015:8(1):20.

29. Sambrook J, Russell David W. Molecular cloning: a laboratory manual. Cold Spring Harb Lab Press. 1989:3(2):253.

30. Tripathi SA, Olson DG, Argyros DA, Miller BB, Barrett TF, Murphy DM, et al. Development of pyrF-based genetic system for targeted gene deletion in Clostridium thermocellum and creation of a pta mutant. Appl Environ Microbiol. 2010;76(19):6591-9.

31. Beguin $P$, Cornet $P$, Aubert JP. Sequence of a cellulase gene of the thermophilic bacterium Clostridium thermocellum. J Bacteriol. 1985;162(1):102-5.

32. Bräu B, Sahm H. Cloning and expression of the structural gene for pyruvate decarboxylase of Zymomonas mobilis in Escherichia coli. Arch Microbiol. 1986:144(3):296-301.

33. Bradford MM. A rapid and sensitive method for the quantitation of microgram quantities of protein utilizing the principle of protein-dye binding. Anal Biochem. 1976;72(1):248-54.

34. Orencio-Trejo M, Flores N, Escalante A, Hernández-Chávez G, Bolívar F, Gosset $\mathrm{G}$, et al. Metabolic regulation analysis of an ethanologenic Escherichia coli strain based on RT-PCR and enzymatic activities. Biotechno Biofuels. 2008;1(1):8.

35. Stackler B, Christensen EN. Quantitative Determination of Ethanol in Wine by Gas chromatography. Am J Enol Vitic. 1974;25(4):202-7.

36. Seo HB, Kim HJ, Lee OK, Ha JH, Lee HY, Jung KH. Measurement of ethano concentration using solvent extraction and dichromate oxidation and its application to bioethanol production process. J Ind Microbiol Biotechnol. 2009:36(2):285-92.

\section{Submit your next manuscript to BioMed Central and we will help you at every step:}

- We accept pre-submission inquiries

- Our selector tool helps you to find the most relevant journal

- We provide round the clock customer support

- Convenient online submission

- Thorough peer review

- Inclusion in PubMed and all major indexing services

- Maximum visibility for your research

Submit your manuscript at www.biomedcentral.com/submit 